\title{
The Effects of the Primary Nursing Care Model: A Systematic Review
}

\author{
Elina Mattila ${ }^{1^{*}}$, Anneli Pitkänen ${ }^{2}$, Seija Alanen ${ }^{3}$, Kaija Leino $^{4}$, Katja Luojus $^{5}$, Anja Rantanen ${ }^{6}$ and Pirjo Aalto $^{7}$ \\ ${ }^{1}$ Director of Nursing, Tampere University Hospital, Tampere, Finland. \\ ${ }^{2}$ Director of Nursing, Pirkanmaa Hospital District, Tampere University Hospital, Tampere, Finland. \\ ${ }^{3}$ Director of Nursing, Department of Neurosciences and Rehabilitation, Tampere University Hospital, Tampere, Finland. \\ ${ }^{4}$ Director of Nursing, Division of Surgery, Gastroenterology and Oncology, Tampere University Hospital, Tampere, Finland. \\ ${ }^{5}$ Project Manager, TAITO project, Pirkanmaa Hospital District, Tampere University Hospital, Tampere, Finland. \\ ${ }^{6}$ Postdoctoral researcher, School of Health Sciences, Nursing Science, University of Tampere, Tampere, Finland. \\ ${ }^{7}$ Chief Nursing Director, Administration Center, Pirkanmaa Hospital District, Tampere University Hospital, Tampere, Finland.
}

*Corresponding author: Elina Mattila, PhD, Director of Nursing, Division of Surgery, Gastroenterology and Oncology, Tampere University Hospital, POB 33610 Tampere, Finland; Tel: +358 50 3130373, Fax: +358 3 31164358, E-mail: elina.mattila@pshp.fi

Received date: April 16, 2014, Accepted date: September 24, 2014, Publication date: September 26, 2014

Copyright: (C) 2014 Mattila E, et al. This is an open-access article distributed under the terms of the Creative Commons Attribution License, which permits unrestricted use, distribution, and reproduction in any medium, provided the original author and source are credited.

\begin{abstract}
Background: Nursing care models provide the infrastructure for organizing and delivering care to patients and families. Over the decades, different models have waxed and waned. Since the 1980s, the primary nursing model has gained increasing prominence. However, there is no systematic research evidence on the effects of this model for patients, their family members, nursing staff or the care organization. This subject has much current relevance because of the requirement to develop evidence-based nursing care.
\end{abstract}

Objective: To describe the effects of the primary nursing model for patients, their family members, nursing staff and the care organization.

Design: A systematic literature review. The studies selected for review $(n=9)$ were appraised for quality using the Quality Assessment Tool for Quantitative Studies, as developed by the Effective Public Health Practice Project.

Data sources: The research data were collected from four databases from January 1990 to March 2013.

Results: Research on the effects of the primary nursing model has largely been restricted to the effects for patients and nursing staff. No data are available on how it affects the patient's family members or the care organization. The preliminary evidence suggests that the primary nursing model may have beneficial effects for patients in the context of maternity care. There is less evidence of the primary nursing model's positive effects for nursing staff. However, it is possible that the model contributes to an increased sense of job control and autonomy.

Conclusion: The existing body of research has methodological shortcomings, and more RCT studies are needed to establish the effects of the primary nursing model, for instance on the organization's costs, nurses' job satisfaction and staff retention. Further research is also needed into the effects of the primary nursing model on numerically measurable outcomes, such as medication errors during hospital care and the length of treatment periods.

Keywords: Care model; Evaluation;, Primary nursing; Systematic review

\section{Introduction}

Health care around the world is under mounting pressure to improve efficiency, to manage costs, to document the methods used and to demonstrate the effectiveness of those methods [1]. Hospitals, for instance, are having to work to improve patient flows, reduce the amount of time that patients spend in hospital and to use more bedside technology [2]. It is also required that evidence be produced of the methods that are used in health care [3]. The development of evidence-based nursing requires critical appraisal of the research evidence and integration of that evidence with nurses' clinical experience and patient expectations. The organization's current financial position also comes into play [4,5]. Patients are better informed about their care and medication than before, and they expect to receive high quality and effective care $[3,6]$. Nursing staff, for their part, expect to have a high level of job autonomy and to be able to put their skills and competencies to the best possible use. The need to appraise nursing care delivery models is further underscored by problems with the availability of nursing staff and the challenges of staff retention $[2,6]$.

Nursing care models provide the infrastructure for organizing and delivering care to patients and families [7]. They also reflect the philosophical foundation of patient care as well as the prevailing organizational culture $[8,9]$. Nursing care is based on the changing needs and situation of each individual patient [6]. The focus of adult patient care has shifted increasingly from the individual patient to also involving their family members [10]. Patient care requires increased 
planning, interaction and multi professional collaboration $[6,11]$. The model of care delivery also affects nursing staff numbers, the flexible use of staff resources and therefore the organization's costs [6]. Over the decades, the nursing models applied have ranged from Nightingale's case method to the currently favoured primary nursing and relationship-based care models $[9,12,13]$. However, we still have no firm evidence about the effects of these models for patients, their family members, nursing staff and the care organization or about the outcomes of nursing [14].

Under the primary nursing model, patient care is the responsibility of a named nurse for the duration of the patient's hospital stay. This means that the planning and implementation of care primarily takes place between the patient and named nurse [15-17]. The same nurse assumes overall responsibility for patient care and is answerable to her patient, the patient's family and to her colleagues $[15,18]$. However, the named nurse does not work alone but works closely with colleagues and other professional groups $[18,19]$. The primary nurse delegates the responsibility of the patient's care to associate nurses when off duty $[14,20]$. Wards organized on the principles of primary nursing have a flat organizational structure because patient care is equally shared between nurses [6].

The primary nursing model is widely implemented since it has been considered to be an ideal way of organizing nursing care delivery. It is grounded in a patient-centred approach and it supports nurses' professionalism, autonomy, broad job descriptions and independent decision-making $[8,15]$. The key is that nurses are driven to address patient needs in their work, rather than perform specific job tasks under given functional structures.

The primary nursing model has continued to be rolled out widely since it was first developed in the United States in the late 1960s [18]. It has been implemented, for example, in Canada [21], China [22], the United Kingdom [8], the Netherlands [23] and Finland [24]. In the United States, the model is particularly favoured in hospitals with magnet status [25].

\section{Findings from Previous Studies}

The evidence from earlier research into primary nursing is largely descriptive and much of it is outdated. Some of the results are contradictory. A previous systematic review covered studies published between 1975 and 1990 [26]. In these studies were considerable variations in the definition of the primary care concept and the way primary care was implemented. Also, the measures used to assess the effect of primary care model differed a lot. Thus, making reliable conclusions, or finding a generalizing result, was not possible [26]. However, the consensus seems to be that primary nursing care is beneficial to patients in that it is conducive to more individually tailored care and to the continuity of care. It also gives patients more chance to take part in the planning and implementation of care $[17,27,28]$. Furthermore, the model supports increased communication between the people involved in patient care as well as more accurate information about the patient $[27,29,30]$. It has also been shown that primary nursing correlates positively with patient experiences of access to support [31-33] and a sense of individual care and attention [34]. Finally, the evidence suggests that primary nursing is positively associated with patients' mental well-being and their satisfaction with the care provided $[29,35,36]$. On the other hand, it is reported that primary nursing does not improve patients' perceptions of the quality of care [37].

Earlier research has also shown a positive correlation between primary nursing and nurse experiences of job autonomy and independent decision-making $[27,30,38,39]$, job satisfaction, professional growth, improved professional cooperation in the workplace [16,39] and reduced work-related stress [40,41]. On the other hand, it has also been reported that primary nursing actually increases work-related stress [30]. Furthermore, the evidence is that nurses working in primary nursing contexts spend more time talking with patients and colleagues than nurses in other care delivery settings $[27,42]$. Many studies have indicated that primary nurses have more job autonomy and are more committed to their work than taskoriented and team working nurses $[28,30,43]$. The primary nursing model also reduces nurses' experiences of stress and seems to be conducive to a more positive workplace community [16,38-40]. A recent review suggests that the primary nursing model increases levels of staff retention in the work unit [44].

The previously mentioned literature review covered studies on the effects of the primary nursing model that were published between 1975-1990 [26]. To the best of our knowledge, after 1991 there exists no systematic review of the research evidence on the effects of primary nursing for patients, their family members, nursing staff and the care organization. Given the current commitment to developing evidencebased nursing, this is a subject of much current interest. This study reviews the earlier literature and on this basis discusses the effects achieved with the use of the primary nursing model.

\section{Purpose of the study}

This study reviews the scientific literature on the effects of the primary nursing care model for patients, their family members, nursing staff and the care organization.

\section{Methods}

\section{Search strategy}

The literature was searched in two stages. First, a limited search of CINAHL used the following search terms: primary nursing, primary nurse and named nurse. This search was undertaken to find additional keywords. A second search using all the identified keywords (primary nursing, primary nurse, named nurse, own care worker, designated nurse) and the search term "random allocation", "random sample", "randomized controlled", "quasi experimental", "clinical trial", "evaluation study", "validation study" or "pretest-post-test", was then undertaken by the reviewer (AP) together with an information specialist across the following electronic bibliographic databases: CINAHL, the Cochrane Library and Medline(Figure 1). 


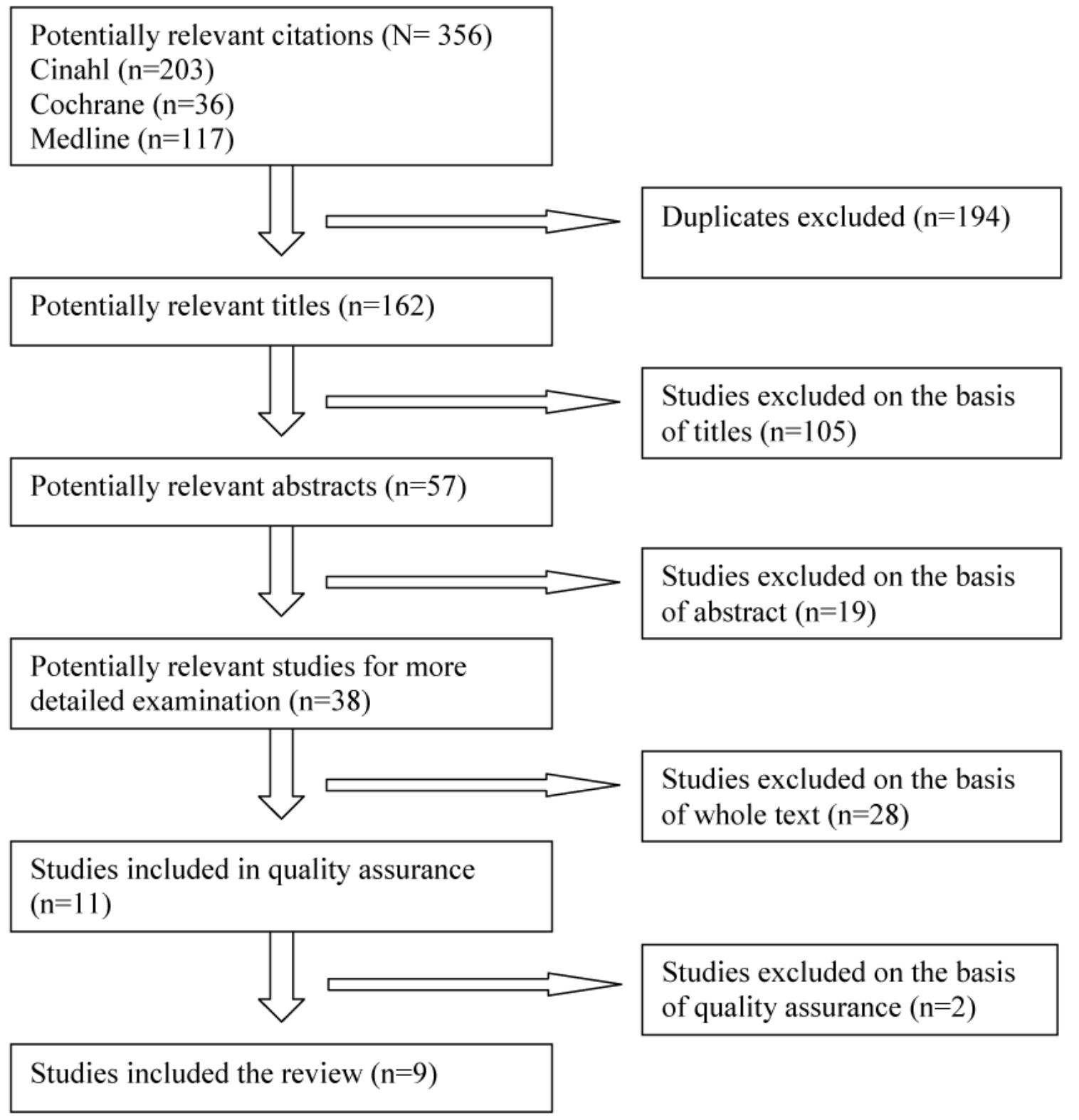

Figure 1: Flowchart of the literature selection process.

\section{Criteria for inclusion}

\section{Study types}

Randomized controlled trials, non-randomized controlled trials and before-and-after studies were selected for inclusion in the review. Only texts written in English and published between January1990 and March 2013 were considered. The search period was restricted to the last 23 years in which the primary nursing model has been rolled out internationally $[8,28]$ and during which time there have been major fundamental changes in health care delivery $[45,46]$. It was furthermore required that the database included an abstract of the article.

\section{Interventions}

The review focused on studies that evaluated primary nursing as a care model. Under this model caring is based on a one-to-one relationship where each patient is assigned a specific primary nurse who assumes 24-hour responsibility and accountability for patients during their stay in care $[13,14]$.

\section{Outcomes}

All outcomes concerning patients, their family members, staff and the care organization were considered.

\section{Study selection}

After the removal of duplicates, two authors (AP, KLe/SA) independently screened the titles of the studies. Studies that were 
clearly not relevant based on their title were excluded. Next, the abstracts of the remaining studies were rated as either "relevant", "uncertain" or "irrelevant", based on the inclusion criteria. In cases where it was not entirely clear whether the study described interventions relevant to this review, the study was included. Finally, studies rated as relevant or uncertain were read in full and screened based on the inclusion criteria. Doubtful titles, abstracts and full articles were discussed among the authors (Figure 1).

\section{Data extraction}

Data were extracted from each paper included in the review by two authors (AR, EM/KLu) independently. These data included specific details about interventions, study methods, participants and outcomes of significance to the review.

\section{Quality appraisal}

The articles were assessed for quality using the Effective Public Health Practice Project (EPHPP) Quality Assessment Tool for
Quantitative Studies criteria (http://www.ephpp.ca/tools.html), which consider quality from six perspectives: 1) selection bias, 2) study design, 3) confounders, 4) blinding, 5) the data collection method and 6) withdrawals and dropouts. Based on the total scores from these perspectives, the quality of each study was classified as strong, moderate or weak.

Quality was assessed for eleven articles that met the inclusion criteria. Two of the three researchers (AR, EM, KLu) independently assessed the quality of each study before the appraisals were compared. In cases where total scores differed, the researchers discussed their assessments until they reached agreement on the most appropriate score. Based on the EPHPP criteria, three of the articles reviewed were rated as strong in quality $[21,22,47]$,six as moderate in quality $[23,28,39,48-50]$ and two as weak in quality [51,52].Nine articles were included in the systematic literature review (Table 1).

\begin{tabular}{|c|c|c|c|c|c|c|c|}
\hline Article & $\begin{array}{l}\text { Selection } \\
\text { bias }\end{array}$ & $\begin{array}{l}\text { Study } \\
\text { Design }\end{array}$ & Confounders & Blinding & $\begin{array}{l}\text { Data collection } \\
\text { method }\end{array}$ & $\begin{array}{l}\text { Withdrawals and } \\
\text { dropouts }\end{array}$ & Final decision \\
\hline Armitage et al. [51] & 2 & 2 & 2 & 3 & 3 & 3 & 3 \\
\hline $\begin{array}{l}\text { Boumans and } \\
\text { Landeweerd[23] }\end{array}$ & 2 & 2 & 1 & 3 & 2 & 2 & 2 \\
\hline Gagnon et al. [21] & 2 & 1 & 1 & 2 & 2 & 1 & 1 \\
\hline Gardner [29] & 2 & 2 & 2 & 2 & 2 & 3 & 2 \\
\hline Gardner and Tilbury [48] & 2 & 2 & 2 & 2 & 2 & 3 & 2 \\
\hline McPhail et al. [52] & 3 & 2 & 3 & 3 & 3 & 2 & 3 \\
\hline Melchior et al. [47] & 2 & 1 & 2 & 1 & 1 & 1 & 1 \\
\hline Melchior et al. [28] & 1 & 2 & 2 & 3 & 1 & 2 & 2 \\
\hline Shields et al. [49] & 2 & 1 & 2 & 2 & 1 & 2 & 2 \\
\hline Spurgeon et al. [50] & 2 & 2 & 2 & 2 & 3 & 2 & 2 \\
\hline Wan et al. [22] & 1 & 1 & 1 & 2 & 2 & 2 & 1 \\
\hline
\end{tabular}

Table 1: EPHPP quality appraisal.

$$
1=\text { strong, } 2=\text { moderate, } 3=\text { weak }
$$

\section{Data analysis}

Because of the wide diversity of types of interventions and outcome measures, it was decided that a quantitative synthesis of the data would not be justified and might be misleading [53]. Instead, content analysis of the interventions was based on a descriptive method [54].

\section{Description of the data}

Studies focusing on patients were conducted in surgical, medical, orthopaedic and maternity contexts $[21,22,39,49,50]$, while studies concerned with nursing staff were conducted on surgical, medical and orthopaedic wards [23,39], as well as psychiatric wards [28,47].In studies which have focused on the organization [39,48], primary nursing and team nursing were compared by each model's nursing costs per patient, per day. The cost included the salaries and fringe benefits for the direct care providers and support persons. In addition, the diagnosis related group (DRG) cost was calculated by length of stay. None of the studies dealt with patients' family members. Three of the studies used RCT designs [21,22,49], the remaining four were intergroup pre-post measurements with control groups $[28,47,50]$ or without them $[22,39,48]$. Sample sizes in experimental groups ranged from 49 to 917 and in control groups from 50 to 651. Response rates ranged from 41 to $100 \%$, and the interventions lasted from seven months to four years. Two studies [49,50] did not report the duration of the intervention (Table 2). The mean age of the people taking part in the studies was between 20 and 60, and most of them were women. The mean age of nursing staff was between 31 and 35 , and their mean period of work experience was 10-13 years.

\section{Description of the interventions}

The primary nursing models examined in the studies, and the interventions through which they were implemented, were quite heterogeneous. In one study the impact of the primary nursing model 
was examined in a general hospital [23] and in two studies in psychiatric hospitals $[28,47]$ in the Netherlands. The remaining six studies $[21,22,39,48-50]$ were conducted in Canada, the USA, Scotland, England and China, in different nursing contexts.

In an earlier study primary nursing was implemented in a Dutch model where primary nursing units were divided into two teams, each of which had two registered nurses responsible for a group of about six patients [23]. This allocation of patients lasted for one work shift, five days a week. According to the authors, the nursing process was the basis for practice. Implementation of this primary nursing model was based on in-service training, on-the-job training and staff development activities aimed at improving nurses' skills in planning, coordination, evaluation and care provision [23].

In the US study the intervention consisted of the implementation of the nursing models of primary units (two) and team units (two) in medical care contexts. The concepts of primary nursing were operationalized using existing literature [39]. Primary nursing and team nursing models were also implemented in a medical care context [48].

In two studies [28,47] primary nursing was implemented in a psychiatric care context. The content of primary nursing was described to be based on the general principles of primary nursing. In this case both psychiatric and practical nurses were assigned as named nurses to patients based on the complexity of care. Nurse managers or quality care co-ordinators were actively involved in order to provide feedback, support and advice, and to promote communication between primary nurses and other health care specialists. Primary nurses were also enrolled in a training programme focusing on communication skills $[28,47]$.

The four models applied in the context of midwife-led care differed from each other most particularly in the length of the care process. In two models $[49,50]$ the named midwife or associate nurse was responsible for care provision from the antenatal to postnatal periods, and in the other two models $[21,22]$ only during hospitalization. In the two studies, midwives worked to a shared philosophy emphasizing continuity of care, information and choice, and informed care planning $[49,50]$. In the other study the usual one-to-one nursing care was enriched by the provision of physical comfort, emotional support, and instruction on relaxation for women and support for fathers. Nurses were in charge of contacting a physician or anesthesiologist when appropriate [21]. One study claimed that the continuous primary nursing care they implemented is based on, and goes beyond, primary nursing since it continues two weeks after discharge [22]. The practical implementation of the interventions is only described in one study [21]. In that study, nurses had a 30-hour training period and quarterly refresher workshops [21].

\section{Results}

\section{Effects for patients}

\section{Satisfaction with care}

Three of the studies reviewed were concerned with the associations between primary nursing and patients' satisfaction with care. These studies focused on pregnant, childbearing and newly delivered mothers $[22,49,50]$.

Patient satisfaction was assessed based on patient-nurse relationships, information transfer, social support, continuity of care, involvement in decision-making and chances to choose different care options. Patients in both the experimental and control groups were satisfied with the care they received [49]. However, patients in the experimental group, where care delivery was based on the primary nursing model, were at all stages significantly more satisfied with their care on all dimensions. Experimental group patients were significantly more satisfied than control group patients with the care they received during pregnancy weeks 34-35 $\quad(\mathrm{p}<0.0001)$, during delivery $(\mathrm{p}=0.0005)$, after delivery, in hospital $(\mathrm{p}=0.002)$, after discharge from hospital $(\mathrm{p}<0.0001)$ and during the seven-month follow-up $(\mathrm{p}<0.0001)$ (49) (Table 2).

\begin{tabular}{|c|c|c|c|c|c|c|}
\hline Study & $\begin{array}{l}\text { Setting and } \\
\text { participants }\end{array}$ & Study design & Intervention & Duration & $\begin{array}{l}\text { Outcome variables, } \\
\text { Instruments }\end{array}$ & Results \\
\hline \multirow[t]{4}{*}{$\begin{array}{l}\text { Boumans and } \\
\text { Landeweerd, } \\
{[23]}\end{array}$} & \multirow[t]{4}{*}{$\begin{array}{l}\text { An } 850 \text {-bed hospital, } \\
59 \quad(n=145) \text { nurses } \\
\text { who participated in all } \\
\text { three measurements. }\end{array}$} & \multirow[t]{4}{*}{$\begin{array}{l}\text { Pre-post } \\
\text { (without control group) }\end{array}$} & \multirow{4}{*}{$\begin{array}{l}\text { Implementation of a } \\
\text { Dutch form of primary } \\
\text { nursing: units were } \\
\text { divided into two teams } \\
\text { where two RNs were } \\
\text { responsible for six } \\
\text { patients. }\end{array}$} & \multirow[t]{4}{*}{$\begin{array}{l}14 \text { months: } \\
\text { March 1992- } \\
\text { May } 1993\end{array}$} & $\begin{array}{l}\text { Job satisfaction: } \\
- \text { questionnaire (42 items) } \\
1\end{array}$ & $\begin{array}{|ll|}\begin{array}{l}\text { No } \\
\text { differences. }\end{array} & \text { significant } \\
\end{array}$ \\
\hline & & & & & $\begin{array}{l}\text { Experienced job } \\
\text { significance } \\
\text { - questionnaire (11 items) } \\
1\end{array}$ & $\begin{array}{l}\text { No significant } \\
\text { differences due to } \\
\text { implementation. } \\
\text { Experienced job } \\
\text { significance decreased } \\
\text { before implementation. }\end{array}$ \\
\hline & & & & & $\begin{array}{l}\text { Health complaints: } \\
\text { - Dutch VOEG scale } \\
\text { (21 items) }\end{array}$ & $\begin{array}{l}\text { No } \\
\text { differences. }\end{array}$ \\
\hline & & & & & $\begin{array}{l}\text { Frequency and duration } \\
\text { of absence from work } \\
\text { - Self-reported }\end{array}$ & $\begin{array}{ll}\text { No } & \text { significant } \\
\text { differences. }\end{array}$ \\
\hline Gagnon et al. [21] & $\begin{array}{l}\text { A 637-bed tertiary } \\
\text { care hospital, }\end{array}$ & $\mathrm{RCT}$ & $\begin{array}{l}\text { Implementation of one- } \\
\text { to-one nursing care by } \\
\text { a } \quad 30 \text {-hour initial }\end{array}$ & $\begin{array}{l}15 \text { months: } \\
\text { January } 1993- \\
\text { July } 1994\end{array}$ & $\begin{array}{l}\text { Clinical outcomes: } \\
\text { - Cesarean section rate }\end{array}$ & $\begin{array}{l}\text { Reduced risk of } \\
\text { oxytoxin stimulation but }\end{array}$ \\
\hline
\end{tabular}


Citation: Mattila E, Pitkänen A, Alanen S, Leino K, Luojus K et al. (2014) The Effects of the Primary Nursing Care Model: A Systematic Review. J

\begin{tabular}{|c|c|c|c|c|c|c|}
\hline & $\begin{array}{l}209 \text { women in the } \\
\text { experimental group } \\
\text { and } 204 \text { in the control } \\
\text { group. } \\
11 \text { drop-outs in the } \\
\text { experimental group. }\end{array}$ & & $\begin{array}{l}\text { training period and } \\
\text { quarterly refresher } \\
\text { workshops for nurses }\end{array}$ & & $\begin{array}{l}\text { - Cesarean section due to } \\
\text { cephalopelvic } \\
\text { disproportion or failure to } \\
\text { progress } \\
\text { - epidural analgesia } \\
\text { - oxytocin stimulation } \\
\text { - admission to neonatal } \\
\text { ICU } \\
\text { - duration of labour } \\
\text { - instrumental delivery } \\
\text { - perineal trauma } \\
\text { Review of medical } \\
\text { records }\end{array}$ & $\begin{array}{l}\text { no other significant } \\
\text { differences. }\end{array}$ \\
\hline Gardner [39] & $\begin{array}{l}\text { Medical units in a } \\
526 \text {-bed urban tertiary } \\
\text { care teaching } \\
\text { hospital, } \\
\mathrm{n}=386 \quad \text { patients, } \\
\mathrm{n}=138 \text { nurses } \\
\begin{array}{l}\text { Cost analysis } 13681 \\
\text { patients }\end{array}\end{array}$ & $\begin{array}{l}\text { Pre-post } \\
\text { 3measurements } \\
\text { (with control group) }\end{array}$ & $\begin{array}{lrr}\text { The intervention } \\
\text { consisted of } \\
\text { implementation } \\
\text { primary and } \\
\text { nursing. }\end{array}$ & 4 years & $\begin{array}{l}\text { Quality of nursing care: } \\
\text { - quality of nursing care } \\
\text { - patient hospital stress } \\
\text { - nursing support } \\
\text { - nurses' stress } \\
\text { - direct care activities } \\
\text { - nursing retention } \\
\text { Quality Patient Care } \\
\text { Scale (68 items) } \\
\text { Hospital Stress Rating } \\
\text { Scale (49 items) } \\
\text { Nursing Support Scale } \\
\text { (52 items) } \\
\text { Nursing Stress Scale (44 } \\
\text { items) } \\
\text { Percent of direct care } \\
\text { activities } \\
\text { Cost: } \\
\text { - nursing cost (salaries } \\
\text { and fringe benefits) } \\
\text { - nursing cost per patient } \\
\text { per day } \\
\text { - DRG cost analysis, } \\
\text { patient length of stay }\end{array}$ & $\begin{array}{l}\text { There was significant } \\
\text { higher quality in nursing } \\
\text { care in primary nursing } \\
\text { units. } \\
\text { Patients and nurses } \\
\text { stress } \\
\text { - no significant } \\
\text { differences. } \\
\text { Nursing support } \\
\text { - no significant } \\
\text { differences. } \\
\text { Direct care activities } \\
\text { - no significant } \\
\text { differences. } \\
\text { Nursing retention } \\
\text { - nurses on primary } \\
\text { nursing units were } \\
\text { retained significantly } \\
\text { longer than the nurses } \\
\text { on the team units. } \\
\text { The primary nursing } \\
\text { care model was less } \\
\text { costly than team } \\
\text { nursing. } \\
\text { The primary nursing } \\
\text { costs were lower for } \\
113 \text { DRGs (of a total } \\
201 \text { DRGs), while team } \\
\text { nursing cost were lower } \\
\text { for } 88 \text { DRGs }\end{array}$ \\
\hline $\begin{array}{l}\text { Gardner and } \\
\text { Tilbury } \\
{[48]}\end{array}$ & $\begin{array}{l}\text { General medical units } \\
\text { in a } 526 \text {-bed tertiary } \\
\text { care } \\
\text { hospital. }\end{array}$ & $\begin{array}{l}\text { Pre-post } \\
\text { 3measurements } \\
\text { (with control group) }\end{array}$ & $\begin{array}{l}\text { The use of the primary } \\
\text { nursing model for two } \\
\text { units and team nursing } \\
\text { for the other two units. }\end{array}$ & 4 years & $\begin{array}{l}\text { Costs: } \\
\text { - nursing cost per patient } \\
\text { per day } \\
\text { - nursing costs per DRG }\end{array}$ & $\begin{array}{l}\text { The primary nursing } \\
\text { care model was less } \\
\text { costly than team } \\
\text { nursing. }\end{array}$ \\
\hline \multirow[t]{2}{*}{$\begin{array}{l}\text { Melchior et al. [47] } \\
\text { Melchior et al. } \\
\text { [28] }\end{array}$} & \multirow{2}{*}{$\begin{array}{l}\text { Five psychiatric } \\
\text { hospitals, } \\
\mathrm{n}=161 \text { nurses (60 in } \\
\text { an intervention and } \\
101 \text { in a control } \\
\text { group) who } \\
\text { participated in all } \\
\text { three measurements. } \\
\text { Response rate } 49.4 \% . \\
\text { Five psychiatric } \\
\text { hospitals, }\end{array}$} & \multirow[t]{2}{*}{$\begin{array}{l}\text { Pre-post } \\
3 \text { measurements } \\
\text { (with control group) } \\
\text { Pre-post } \\
3 \text { measurements } \\
\text { (with control group) }\end{array}$} & \multirow{2}{*}{$\begin{array}{l}\text { Implementation of } \\
\text { primary nursing } \\
\text { consisted of assigning } \\
\text { nurses to patients as } \\
\text { primary nurses, } \\
\text { support, advice on the } \\
\text { skills needed and the } \\
\text { promotion } \\
\text { communication } \\
\text { between nurses and } \\
\text { other health care } \\
\text { providers by managers } \\
\text { The implementation of } \\
\text { primary nursing }\end{array}$} & \multirow[t]{2}{*}{$\begin{array}{l}2.5 \text { years } \\
2.5 \text { years }\end{array}$} & $\begin{array}{l}\text { Burnout: } \\
\text { - emotional exhaustion } \\
\text { - depersonalization } \\
\text { - personal } \\
\text { accomplishment } \\
\text { Maslach Burnout } \\
\text { Inventory (22 items) }\end{array}$ & $\begin{array}{l}\text { No significant } \\
\text { differences. }\end{array}$ \\
\hline & & & & & $\begin{array}{l}\text { Job turnover } \\
\text { Work environment: } \\
\text {-tasks of the nurse }\end{array}$ & $\begin{array}{l}\text { No significant } \\
\text { differences. } \\
\text { The frequency of } \\
\text { performing personal }\end{array}$ \\
\hline
\end{tabular}


Citation: Mattila E, Pitkänen A, Alanen S, Leino K, Luojus K et al. (2014) The Effects of the Primary Nursing Care Model: A Systematic Review. J

\begin{tabular}{|c|c|c|c|c|c|c|}
\hline & $\begin{array}{l}\mathrm{n}=176 \text { nurses (64 in } \\
\text { an intervention and } \\
112 \text { in a control } \\
\text { group). } \\
\text { Response rate } 54 \% .\end{array}$ & & $\begin{array}{l}\text { consisted of assigning } \\
\text { nurses to patients as } \\
\text { primary nurses, } \\
\text { support, advice on the } \\
\text { skills needed, and the } \\
\text { promotion } \\
\text { communication of } \\
\text { between nurses and } \\
\text { other health care } \\
\text { providers by managers }\end{array}$ & & $\begin{array}{l}\text { Task Inventory ( } 77 \text { items) } \\
\text { and interviews } \\
\text {-job characteristics } \\
\text { Questionnaire }(48 \text { items })^{1} \\
\text {-leadership style } \\
\text { Leadership Behaviour } \\
\text { Questionnaire ( } 21 \text { items) } \\
\text { - nursing care model } \\
\text { Questionnaire (? items) } \\
\text {-nursing process } \\
\text { Questionnaire }(19 \text { items })^{1}\end{array}$ & $\begin{array}{l}\text { care tasks decreased in } \\
\text { the intervention and } \\
\text { increased in the control } \\
\text { sub-groups with a lower } \\
\text { level of personal care } \\
\text { tasks in the pre-test. } \\
\text { The complexity of work } \\
\text { decreased more in the } \\
\text { intervention sub-group } \\
\text { with a high degree of } \\
\text { complexity. } \\
\text { Autonomy increased } \\
\text { more in the intervention } \\
\text { sub-group with a low } \\
\text { level of autonomy. } \\
\text { No significant } \\
\text { differences. } \\
\text { No significant } \\
\text { differences. } \\
\text { No significant } \\
\text { differences. }\end{array}$ \\
\hline Shields et al. [49] & 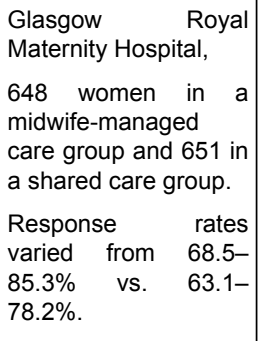 & $\mathrm{RCT}$ & $\begin{array}{l}\text { Each woman had a } \\
\text { named midwife who } \\
\text { provided the majority } \\
\text { of planned care from } \\
\text { the first antenatal visit } \\
\text { to the discharge of the } \\
\text { health visitor }\end{array}$ & $?$ & $\begin{array}{l}\text { Satisfaction with care: } \\
\text { - relationship with staff } \\
\text { - information transfer } \\
\text { - choices and decisions } \\
\text { - social support } \\
2 \text { questionnaires (? items) }\end{array}$ & $\begin{array}{l}\text { Satisfaction } \\
\text { significantly higher in } \\
\text { the midwife-managed } \\
\text { group in all outcomes. } \\
\text { For continuity of care, } \\
\text { more positive } \\
\text { comments were given } \\
\text { by women receiving } \\
\text { midwife-managed care. }\end{array}$ \\
\hline \multirow[t]{3}{*}{$\begin{array}{l}\text { Spurgeon et al. } \\
\text { [50] }\end{array}$} & \multirow[t]{3}{*}{$\begin{array}{l}112 \text { and } 103 \text { women } \\
\text { in pilot groups and } \\
118 \text { women in a } \\
\text { control group. } \\
\text { No drop-outs, } \\
\text { retrospective study. }\end{array}$} & \multirow[t]{3}{*}{$\begin{array}{l}\text { Retrospective } \\
\text { between-groups }\end{array}$} & \multirow[t]{3}{*}{$\begin{array}{l}\text { Implementation of } \\
\text { midwifery-led care. }\end{array}$} & \multirow[t]{3}{*}{$\begin{array}{l}\text { January } 1997 \\
>?\end{array}$} & $\begin{array}{l}\text { Satisfaction with care: } \\
\text { - personal preferences }\end{array}$ & $\begin{array}{l}\text { Pilot groups felt they } \\
\text { had more choice about } \\
\text { where they could give } \\
\text { birth and who would } \\
\text { deliver the baby. They } \\
\text { also felt they had the } \\
\text { name of a contact } \\
\text { person when advice } \\
\text { was needed. Group A } \\
\text { rated the value of } \\
\text { parent craft classes } \\
\text { higher than others. }\end{array}$ \\
\hline & & & & & - antenatal care & $\begin{array}{l}\text { The control group had } \\
\text { too few checks at home } \\
\text { and more often the first } \\
\text { check was at a GP } \\
\text { clinic rather than at } \\
\text { home. } \\
\text { Pilot groups were more } \\
\text { satisfied rith } \\
\text { information and staff in } \\
\text { several areas. They } \\
\text { also rated the } \\
\text { importance of the } \\
\text { continuity of care } \\
\text { higher than the control } \\
\text { group. }\end{array}$ \\
\hline & & & & & - labour and delivery & $\begin{array}{l}\text { Pilot groups were more } \\
\text { satisfied with midwifes } \\
\text { in several areas. No } \\
\text { significant differences } \\
\text { in clinical outcomes. }\end{array}$ \\
\hline
\end{tabular}




\begin{tabular}{|c|c|c|c|c|c|c|}
\hline & & & & & - postnatal care & $\begin{array}{l}\text { Pilot groups were more } \\
\text { satisfied with midwifes } \\
\text { in several areas. }\end{array}$ \\
\hline & & & & & $\begin{array}{l}\text { - information and advice } \\
\text { Questionnaire (? items) }\end{array}$ & $\begin{array}{l}\text { Pilot groups were } \\
\text { significantly more } \\
\text { satisfied with the level } \\
\text { of information received } \\
\text { on some aspects of } \\
\text { care. }\end{array}$ \\
\hline & & & & & $\begin{array}{l}\text { Clinical outcomes: } \\
\text { - average length of labour } \\
\text { - use of pain control } \\
\text { - type of delivery } \\
\text { - incidence of perineal } \\
\text { tearing } \\
\text { - birth weight } \\
\text { - APGAR scores } \\
\text { Medical records. }\end{array}$ & $\begin{array}{ll}\text { No } & \text { significant } \\
\text { difference. }\end{array}$ \\
\hline \multirow[t]{3}{*}{$\begin{array}{l}\text { Wan et al. } \\
\text { [22] }\end{array}$} & \multirow[t]{3}{*}{$\begin{array}{l}\text { Shanghai r rirst } \\
\text { Maternity and Infant } \\
\text { Health Hospital, } \\
230 \text { women in the } \\
\text { intervention and } 240 \\
\text { in a control group. } \\
\text { No drop-outs. }\end{array}$} & \multirow[t]{3}{*}{$\mathrm{RCT}$} & \multirow[t]{3}{*}{$\begin{array}{lr}\text { Nurses were trained to } \\
\text { provide } & \text { consistent } \\
\text { continuous } & \text { nursing } \\
\text { care. } & \end{array}$} & \multirow[t]{3}{*}{$\begin{array}{l}7 \text { months: } \\
\text { December } \\
2008-J u n e \\
2009\end{array}$} & $\begin{array}{l}\text { Satisfaction with care: } \\
-\quad \text { environment and } \\
\text { facilities } \\
-\quad \text { attitude and } \\
\text { communication } \\
\text { - ward administration } \\
\text { - practice skills and ability } \\
\text { - health education } \\
\text { Questionnaire }(30 \text { items })^{1}\end{array}$ & $\begin{array}{l}\text { Satisfaction with } \\
\text { nursing care was } \\
\text { significantly higher in } \\
\text { almost all areas in the } \\
\text { intervention group. }\end{array}$ \\
\hline & & & & & $\begin{array}{l}\text { Knowledge of } \\
\text { breastfeeding } \\
\text { - questionnaire (17 items) }\end{array}$ & $\begin{array}{llr}\text { Mothers } & \text { in } & \text { the } \\
\text { intervention } & \text { group } & \text { felt } \\
\text { significantly } & \text { more } \\
\text { knowledgeable } & \text { in } \\
\text { breastfeeding. } & \end{array}$ \\
\hline & & & & & $\begin{array}{l}\text { Clinical outcomes: } \\
\text { - postpartum urinary } \\
\text { retention } \\
\text { - breastfeeding } \\
\text { - breast discomfort } \\
\text { Medical records. }\end{array}$ & $\begin{array}{l}\text { The breastfeeding rate } \\
\text { was higher in the } \\
\text { intervention group. } \\
\text { The occurrence of early } \\
\text { postpartum health } \\
\text { problems was lower in } \\
\text { the intervention group. }\end{array}$ \\
\hline
\end{tabular}

Table 2: An overview of the studies included in the review.

One study reported that patients in both the experimental and control groups were satisfied with the care they received at different stages of pregnancy, delivery and puerperium [50]. However, experimental group patients who had their own designated midwife were more satisfied than control group patients with their chance to choose where they wanted to give birth $(\mathrm{p}<0.001)$ and their midwife $(\mathrm{p}<0.001)$. Furthermore, patients in the experimental group were more satisfied than patients in the control group with the information they had received about their care and about preparing for childbirth $(p<0.01)$. During delivery experimental group patients were more aware than control group patients about events during childbirth $(p<0.001)$, they felt their needs were taken into account and that they were understood $(p<0.01-0.05)$, and that they were not left alone for long periods $(\mathrm{p}<0.01)$. In addition, experimental group patients were more aware of their postnatal counsellor whom they could contact for advice $(p<0.001)$, and they rated the value of the antenatal/parent craft classes more highly than did patients in the experimental group $(p<0.05)$. The experimental group patients felt that they were offered fewer checks at home than did patients in the control group $(\mathrm{p}<0.05)$ [50] (Table 2).

The Chinese study reported that experimental group patients (whose care was delivered according to the primary nursing model) were more satisfied with their care environment and its facilities $(\mathrm{p}<0.001)$, nurse communication and attitudes $(\mathrm{p}<0.001)$, ward administration $(\mathrm{p}<0.001)$, practice skills and ability $(\mathrm{p}<0.001)$, and with health education/guidance $(\mathrm{p}<0.001)$ [22] (Table 2).

\section{Nursing support and patient hospital stress}

The US study showed that support from nurses did not differ significantly between the patients in primary and team nursing units. 
Neither did stress experienced by patients during the inpatient care differ significantly between these two nursing models [39] (Table 2).

\section{Childbirth and newborn care}

The maternal context study discovered that experimental group mothers who had the same named midwife throughout childbirth used significantly less oxytocin to aid delivery than control group mothers, whose midwives changed shift during delivery (the relative risk of experimental group versus control group $=0.83$; a $95 \%$ confidence interval $=0.67,1.04)$ (Table 2$)$. By contrast, primary nursing had no positive effect on the number of Caesarean sections, the duration of delivery, pain relief or procedures during delivery. Likewise, primary nursing showed no association with newborn APGAR scores, the need for monitoring or birth weight $[21,50]$ (Table 2).

\section{Breastfeeding newborn babies}

Mothers in the experimental group were more aware of breastfeeding issues than control group mothers $(p<0.001)$ and breastfed their baby more often in hospital $(\mathrm{p}<001)$ and six weeks after childbirth $(\mathrm{p}<0.001)$ [22] (Table 2).

\section{Postpartum health problems}

The Chinese study reported that mothers in the experimental group developed postpartum urinary retention significantly less often than mothers in the control group $(\mathrm{p}<0.002)$. In addition, mothers in the experimental group suffered from breast discomfort less often than mothers in the control group $(\mathrm{p}<0.001)$ [22] (Table 2).

\section{Effects for nursing staff}

\section{Job characteristics}

The Dutch study assessed job characteristics on three dimensions, viz. job autonomy, feed back/clarity and job complexity. Intervention group nurses who worked under a primary nursing model felt the complexity of their job decreased more than did nurses in the control group $(\mathrm{p}<0.001)$. Furthermore, nurses in the experimental group felt they had more job autonomy than nurses in the control group $(\mathrm{p}<0.001)$ [28] (Table 2). By contrast, the primary nursing model had no effect on nurses' job satisfaction, burnout, stress, sense of meaning in their work, health complaints, absenteeism or staff retention in the unit $[23,28,39]$. However, in the other study [28], turnover among nurses in the primary nursing units was significantly lower during the three year follow-up period than in the team nursing units $(\mathrm{p}<0.01)$.No significant association was discovered between primary nursing and leadership style [28] (Table 2).

\section{Tasks of the nurse}

The Dutch study was interested in studying the range of tasks performed by nurses during one work shift. Nursing tasks were divided into four categories, i.e. personal care tasks, psychosocial tasks, household tasks and organizational tasks. According to the results, experimental group nurses who worked as named nurses under a primary nursing model performed fewer personal care tasks than control group nurses $(\mathrm{p}<0.05)$. In other categories no significant differences were discovered (Table 2) [28].In another study no significant differences were found between primary and team nursing units on the amount of nurses' care activities for patients [39] (Table 2).

\section{Quality of care}

In both a one-year and 2.5-year follow-up, the nurses in the primary nursing units assessed their unit's quality of care to be of significantly higher quality than did the nurses in the team nursing units when assessing their own units $(\mathrm{p}<0.01)$ [39] (Table 2).

\section{Effects for the organization}

\section{Costs of the nursing}

One study showed that the primary nursing model was $6.5 \%$ less costly than team nursing in 36 six-month follow-up periods [48]. Also, nursing costs per patient by DRG were $12-16 \%$ lower in the primary nursing units than in the team nursing units [48]. Another study found that costs per patient per day in the primary nursing units were lower than in the team nursing units $(\mathrm{p}<0.05)$ [48]. When studying nursing costs for 201 DRGs by length of stay, primary nursing costs were lower for 113 DRGs (56\% of the 201), while team nursing costs were lower for 88 DRGs (44\% of the 201). The lower costs of the primary nursing model compared to the team nursing model were explained by lower number of administration staff, a higher patientstaff ratio and less use of agency nurses $(39,48)$ (Table 2$)$.

\section{Discussion}

\section{Discussion of the results}

It is clear from the results of our review that we still know very little about the effects of primary nursing practice. Research so far has focused mostly on patients and nursing staff, whereas patient's family members and organizational factors have largely been sidelined. However, the focus of nursing care today is shifting increasingly from the treatment of individual patients to considering their whole families $[10,55]$. In this line of research, therefore, it is important to consider the position of family members as well. From an organizational point of view, information is needed about the cost implications of nursing care delivery models, the outcomes of different care models and what kinds of models are needed for the flexible use of nursing staff resources and staff retention. Based on the findings of this study, the primary nursing model is more cost-effective than the team nursing way of caring for patients. In the primary nursing model the nurses care for patients in a comprehensive way and the number of administration staff is lower.

The results indicate that there is a scarcity of research using RCT and other experimental designs. There is somewhat more descriptive research but that did not meet the inclusion criteria established for this review. It is quite surprising to find such a scarcity of evidence given that primary nursing has been considered the ideal model for care delivery for decades [8]. Whether or not this model really is the best system for care delivery cannot be established on the basis of this review. For that purpose we will need to have more research using RCT designs. However, it is important to note that primary nursing care does not just mean a certain way of allocating patients to nurses but is also, importantly, a philosophical premise for nursing care delivery that centres around the patient. Indeed, recent studies have used the concept of relationship-based nursing, which comprises primary nursing thinking and which stresses patient-nurse interaction, the nurse's professional responsibility for patient care and nurses' collaboration in patient care $[9,12,56]$. The duality of the primary nursing concept makes the accumulation of the necessary evidence a highly challenging task. In fact, the quality of patient-nurse 
interaction may be a more significant factor than the model of nursing care delivery itself.

The results of this review lead us to the preliminary conclusion that the primary nursing model has positive effects for patients in the contexts of care during pregnancy, childbirth and puerperium. The model increases women's satisfaction with care, encourages a more positive attitude to breastfeeding and reduces postpartum health problems. This result may be explained by women's emotional sensitivity during pregnancy and childbirth that makes them more receptive, for instance to the care and counselling provided by named nurses, which in turn is reflected in improved self-care and breastfeeding skills. If the primary nursing model can help to reduce health-related problems, that is obviously a significant human factor but, at the same time, it will also contribute to driving down health care costs.

The results of this review raise the interesting question of whether primary nursing is a model that has universal application in all nursing care contexts or whether it is necessary to have different models for different environments and situations. For instance, does a newly graduated nurse have the skills and competencies she will need in order to work under a primary nursing model or would a team working model produce better results in patient care? The results here suggest that the primary nursing model had fewer positive effects for nursing staff than for patients. However, there was also some indication that the primary nursing model enhances nurses' sense of job control and autonomy. In primary nursing the organizational structure is flat [6], which might be reflected in nurses' experiences of job autonomy. On the other hand, the findings here indicate that the nursing model is not associated with job satisfaction. The findings of an earlier study produced contradictory knowledge about the primary nursing model's impact on nurses' retention in the unit. Based on the recent research findings, the nurses who work based on the primary nurse model more often remained in their work place than nurses who work based on other models [44].

\section{Strengths and Limitations of the Review}

The review was restricted to studies that met pre-specified inclusion criteria. The repeatability of the search strategy and the research team's systematic collaboration in selecting and analysing the research data contributed to strengthening the reliability of the review [54,57], as did the team's previous experience in conducting systematic reviews. The search words and databases used were chosen in consultation with the university library's information specialists; this helped to identify a list of the studies that were most directly relevant to our theme. The contents of the studies were carefully assessed and tabulated. Reliability was also enhanced by going back on several occasions to the original studies in order to ensure that their contents had been correctly understood [57]. The quality of the studies reviewed was assessed on the basis of a unified set of criteria. Further, the studies included in the review had been peer reviewed and published in scientific journals.

However, there are also some limitations to this review. First, the list of search words did not include "relationship-based care", and therefore it is possible that some relevant studies were lost. The reason we chose not to use this search word was that we considered it to form an integral part of primary nursing and to describe patient-nurse interaction rather than the actual model of nursing care delivery. Second, the research data were selected on the basis of the title, the resulting selection was refined by the abstract and the results then further refined on the basis of the full text. This means it is possible that relevant studies have been excluded from the review on the basis of their titles. Third, the reliability of the instruments used in the studies must be critically examined. Some of these instruments, particularly those measuring nurses' job satisfaction and job characteristics, were specifically developed for the research in question (Table 2). It is possible that these indices were still under development and therefore the results they produce must be considered with caution. Also, some of the studies were fairly old. Finally, the limitation of our systematic review largely reflects the scarcity(as well as the shortcomings) of the studies reviewed. More rigourous RCT studies are needed to establish the effects of the primary nursing model.

\section{Further Study Challenges}

Future studies should try to establish the effects of the primary nursing model on numerically measurable outcomes, such as the use of health care services, the length of treatment periods, medication errors and the prevalence of infections during hospital care. More RCT studies are also needed to establish the effects of the primary nursing model, for instance on the organization's costs, nurses' job satisfaction, autonomy and staff retention.

\section{Conclusion}

Based on the findings of this review, it seems that the primary nursing model may have beneficial effects for patients in the contexts of care during pregnancy, childbirth and puerperium. It seems to add to patient satisfaction with care and reduce postpartum health problems. It is also possible that the model contributes to nurses' increased sense of job control and autonomy. There is also preliminary evidence that the costs of the primary nursing model are lower than those of the team nursing model. In the future, family members will be increasingly involved in patient care, and therefore it is important to understand how nursing under the primary nursing model supports the coping of the patient's family members during periods of hospitalization.

\section{Contributions}

Conception and design of the study: Elina Mattila, Anneli Pitkänen, Pirjo Aalto

\section{Acquisition of data: Anneli Pitkänen}

Data selection: Elina Mattila, Anneli Pitkänen, Pirjo Aalto, Seija Alanen, Katja Leino, Katja Luojus, Anja Rantanen

Data analysis: Elina Mattila, Anneli Pitkänen, Seija Alanen, Pirjo Aalto

Drafting and revision of the article: Elina Mattila, Anneli Pitkänen, Seija Alanen, Kaija Leino, Katja Luojus, Anja Rantanen, Pirjo Aalto

\section{Conflict of interests}

None

\section{References}

1. Simpson RL (2004) Evidence-based nursing offers certainty in the uncertain world of healthcare. Nurs Manage 35: 10, 12. 
2. Fairbrother G, Jones A, Rivas K (2010) Changing model of nursing care from individual patient allocation to team nursing in the acute inpatient environment. Contemp Nurse 35: 202-220.

3. Leufer T, Cleary-Holdforth J (2009) Evidence-based practice: improving patient outcomes. Nurs Stand 23: 35-39.

4. Ciliska DK, Pinelli J, DiCenso A, Cullum N (2001) Resources to enhance evidence-based nursing practice. AACN Clin Issues 12: 520-528.

5. DiCenso A, Guyatt G, Ciliska D (2005) Evidence-Based Nursing. A guide to clinical practice. Elsevier Mosby, St Louis.

6. Sjetne IS, Veenstra M, Ellefsen B, Stavem K (2009) Service quality in hospital wards with different nursing organization: nurses' ratings. J AdvNurs 65: 325-336.

7. Person C (2004) Patient care delivery. In: Koloroutis E (Ed.) Relationship-based care. A model for transforming practice Minneapolis, MN: Creative Health Care Management. 159-182

8. Rigby A, Leach C, Greasley P (2001) Primary nursing: staff perception of changes in ward atmosphere and role. J PsychiatrMent Health Nurs 8: 525-532.

9. Winsett RP, Hauck S (2011) Implementing relationship-based care. J NursAdm 41: 285-290.

10. Eggenberger SK, Nelms TP (2007) Being family: the family experience when an adult member is hospitalized with a critical illness. J ClinNurs 16: $1618-1628$.

11. Jost SG, Bonnell M, Chacko SJ, Parkinson DL (2010) Integrated primary nursing: a care delivery model for the 21 st-century knowledge worker. NursAdm Q 34: 208-216.

12. Manthey M (2006) Relationship-based care: customized primary nursing. Interview by Marty Lewis-Hunstiger. CreatNurs 12: 4-9.

13. Wright S (1992) My patient my nurse. The practice of primary nursing. Scutari Press. Great Britain.

14. Tiedeman ME, Lookinland S (2004) Traditional models of care delivery: what have we learned? J NursAdm 34: 291-297.

15. Ersser S, Tutton E (1991) Primary Nursing. A Second Look. In: Ersser S, Tutton E (Eds.) Primary Nursing in Perspective. Scutari Press. Great Britain.

16. Mäkinen A, Kivimäki M, Elovainio M, Virtanen M (2003) Organization of nursing care and stressful work characteristics. J AdvNurs 43: 197-205.

17. Thomas LH, Bond S (1990) Towards defining the organization of nursing care in hospital wards: an empirical study. J AdvNurs 15: 1106-1112.

18. Marram G, Barrett M, Bevis E (1979) Primary Nursing. A model for individualized care (2nd ed.). The C.V. Mosby Company, St Louis, Missouri.

19. Manthey M (1980) The Practice of Primary Nursing. Blackwell Scientific, Boston.

20. Sellick KJ, Russell S, Beckmann JL (2003) Primary nursing: an evaluation of its effects on patient perception of care and staff satisfaction. International Journal of Nursing Studies (1983), 20, 265-273. Int J Nurs Stud 40: 545-551.

21. Gagnon AJ, Waghorn K, Covell C (1997) A randomized trial of one-toone nurse support of women in labor. Birth 24: 71-77.

22. Wan H, Hu S, Thobaben M, Hou Y, Yin T (2011) Continuous primary nursing care increases satisfaction with nursing care and reduces postpartum problems for hospitalized pregnant women. Contemp Nurse 37: 149-159.

23. Boumans NP, Landeweerd JA (1999) Nurses' well-being in a primary nursing care setting in The Netherlands. Scand J Caring Sci 13: 116-122.

24. Kivimäki M, Mäkinen A, Elovainio M, Vahtera J, Virtanen M, et al. (2004) Sickness absence and the organization of nursing care among hospital nurses. Scand J Work Environ Health 30: 468-476.

25. Mondino K (2005) The road to excellence: Magnet designation, the Beacon Award, and primary nursing. Crit Care NursClin North Am 17: 163-167, x.

26. Thomas LH, Bond S (1991) Outcomes of nursing care: the case of primary nursing. Int J Nurs Stud 28: 291-314.
27. Manley K, Hamill JM, Hanlon M (1997) Nursing staff's perceptions and experiences of primary nursing practice in intensive care 4 years on. J ClinNurs 6: 277-287.

28. Melchior ME, Halfens RJ, Abu-Saad HH, Philipsen H, van den Berg AA, et al. (1999) The effects of primary nursing on work-related factors. J AdvNurs 29: 88-96.

29. Jonsdottir H (1999) Outcomes of implementing primary nursing in the care of people with chronic lung diseases: the nurses' experience. J NursManag 7: 235-242.

30. Webb C, Pontin D (1996) Introducing primary nursing: nurses' opinions. J ClinNurs 5: 351-358.

31. Fincham L, Copp G, Caldwell K, Jones L, Tookman A (2005) Supportive care: experiences of cancer patients. Eur J OncolNurs 9: 258-268.

32. Mattila E, Kaunonen M, Aalto P, Ollikainen J, Astedt-Kurki P (2010) Support for hospital patients and associated factors. Scand J Caring Sci 24: 734-745.

33. Nelson JE, Kinjo K, Meier DE, Ahmad K, Morrison RS (2005) When critical illness becomes chronic: informational needs of patients and families. J Crit Care 20: 79-89.

34. Suhonen R, Välimäki M, Katajisto J, Leino-Kilpi H (2007) Hospitals' organizational variables and patients' perceptions of individualized nursing care in Finland. J NursManag 15: 197-206.

35. Thomas L, McColl E, Priest J, Bond S (1996) The impact of primary nursing on patient satisfaction. Nurs Times 92: 36-38.

36. Wilson NM, Dawson P (1989) A comparison of primary nursing and team nursing in a geriatric long-term care setting. Int J Nurs Stud 26: $1-13$.

37. Nissen JM, Boumans NP, Landeweerd JA (1997) Primary nursing and quality of care: a Dutch study. Int J Nurs Stud 34: 93-102.

38. Allen DE, Vitale-Nolen RA (2005) Patient care delivery model improves nurse job satisfaction. J ContinEducNurs 36: 277-282.

39. Gardner K (1991) A summary of findings of a five-year comparison study of primary and team nursing. Nurs Res 40: 113-117.

40. Adams A, Bond S, Hale CA (1998) Nursing organizational practice and its relationship with other features of ward organization and job satisfaction. J AdvNurs 27: 1212-1222.

41. Thomas LH (1992) Qualified nurse and nursing auxiliary perceptions of their work environment in primary, team and functional nursing wards. J AdvNurs 17: 373-382.

42. MacGuire J (1989) Primary nursing. A better way to care? Nurs Times 85: 50-53.

43. MacGuire JM, Botting DA (1990) The use of the Ethnograph program to identify the perceptions of nursing staff following the introduction of primary nursing in an acute medical ward for elderly people. J AdvNurs 15: 1120-1127.

44. Butler M, Collins R, Drennan J, Halligan P, O'Mathúna DP, et al. (2011) Hospital nurse staffing models and patient and staff-related outcomes. Cochrane Database Syst Rev : CD007019.

45. American Academy of Nursing (2010) Implementing health care reform: Issues for nursing.

46. World Health Organization (1997). European health care reform. Analysis of current strategies. Who Regional Publications, European Series, No. 72, World Health Organization. Regional Office for Europe, Copenhagen.

47. Melchior ME, Philipsen H, Abu-Saad HH, Halfens RJ, van de Berg AA, et al. (1996) The effectiveness of primary nursing on burnout among psychiatric nurses in long-stay settings. J AdvNurs 24: 694-702.

48. Gardner KG, Tilbury M (1991) A longitudinal cost analysis of primary and team nursing. Nurs Econ 9: 97-104.

49. Shields N, Turnbull D, Reid M, Holmes A, McGinley M, et al. (1998) Satisfaction with midwife-managed care in different time periods: a randomised controlled trial of 1299 women. Midwifery 14: 85-93.

50. Spurgeon P Hicks C, Barwell F (2001) Antenatal, delivery and postnatal comparisons of maternal satisfaction with two pilot Changing Childbirth 
Citation: Mattila E, Pitkänen A, Alanen S, Leino K, Luojus K et al. (2014) The Effects of the Primary Nursing Care Model: A Systematic Review. J Nurs Care 3: 205. doi:10.4172/2167-1168.1000205

Page 12 of 12

schemes compared with a traditional model of care. Midwifery 17: 123-132.

51. Armitage P, Champney-Smith J, Andrews K (1991) Primary nursing and the role of the nurse preceptor in changing long-term mental health care: an evaluation. J AdvNurs 16: 413-422.

52. McPhail A, Pikula H, Roberts J, Browne G, Harper D (1990) Primary nursing. A randomized crossover trial. West J Nurs Res 12: 188-197.

53. Jadad AR, Cook DJ, Jones A, Klassen TP, Tugwell P, et al. (1998) Methodology and reports of systematic reviews and meta-analyses: a comparison of Cochrane reviews with articles published in paper-based journals. JAMA 280: 278-280.
54. Khan KS, Kunz R, Kleijnen J, Antes G (2003) Systematic reviews to support evidence-based medicine, how to review and apply findings of healthcare research. The Royal Society of Medicine Press Ltd, London, UK.

55. Zarubi KL, Reiley P, McCarter B (2008) Putting patients and families at the center of care. comment in J NursAdm 38: 275-281.

56. Schneider MA, Fake P (2010) Implementing a relationship-based care model on a large orthopaedic/neurosurgical hospital unit. OrthopNurs 29: 374-378.

57. Parahoo K (2006) Nursing research principles, process and issues (2nd ed.). Palgrave Macmillan, London. 